\title{
TURBONILLA ELEGANTISSIMA (MONTAGU), A PARASITIC OPISTHOBRANCH
}

\author{
By Vera Fretter \\ Department of Zoology, Birkbeck College, University of London
}

(Text-figs. I-2)

Turbonilla elegantissima (Montagu), though one of the larger and more familiar members of the family Pyramidellidae, is known only by the shell and the appearance of the animal when crawling. Forbes \& Hanley (1853) and Jeffreys (I867) state that it is common around the British Isles, and that its foreign distribution is from Tromsö to the Mediterranean. In the fauna list of the Marine Biological Association (I93I) it is recorded as T. lactea (L.) 'occasionally under stones, particularly where there is a certain amount of silt' from low water to a depth of Io fathoms, and, in the Salcombe estuary, 'very common on the Zostera south of Pilworthy Pt., (Allen \& Todd, 1900)'. Actually this opisthobranch has its own extremely specialized habitat, as do, apparently, all other members of its family (Fretter \& Graham, 1949): like them it is an ectoparasite, restricted to the vicinity of its host. Specimens have been collected from the laminarian zone along the south coast of Devon and Cornwall, the largest number from Church Reef, Wembury, where silt and sand around boulders and between shale ledges provide suitable niches for such sedentary worms as Audouinia tentaculata and Amphitrite gracilis. When covered by the tide the tentacles of these polychaetes extend through the silt and sand and spread over the surface of the rocks for a considerable distance, and it is in the vicinity of these tentacles that Turbonilla lurks to suck liquids from them by means of a long proboscis (Fig. I). Audouinia and Amphitrite were also recorded at Pilworthy Pt., but their association with Turbonilla was then unknown. When the laminarian zone is uncovered the mollusc may wander some distance from its host, in a more superficial position on the shore, clinging to the half-buried stones or just hidden by the silt. It has never been collected from exposed sandy shores, which might offer a suitable habitat for the host, but no safe crannies for the protection of the parasite. Thus Turbonilla burrows to seek its food, and in this respect differs from the Odostomia spp. which have been described (Fretter \& Graham, 1949), for they rest on or near the entrances of the tubes of tubicolous worms, and when they feed the extending proboscis is directed upwards through the water, free of contact with the mentum beneath it, arching over in a U-shaped bend to reach the tissues of the host. Turbonilla, by contrast, is subterranean, ploughing its 
way forwards in search of food and, on sensing it, thrusting out a stout proboscis which is supported by the mentum $(M)$ and pushed through the silt to reach the host. When the feeding process of Turbonilla has been observed in the laboratory the proboscis has been seen to suck blood from the tentacles of Audouinia, even a solitary writhing tentacle fragmented from the worm being pursued and sucked, whilst, if Amphitrite be the prey, either tentacles or gills may be attacked. On no occasion have I seen the proboscis fix itself to the body wall to pierce the worm: presumably this is too stout for penetration to occur.

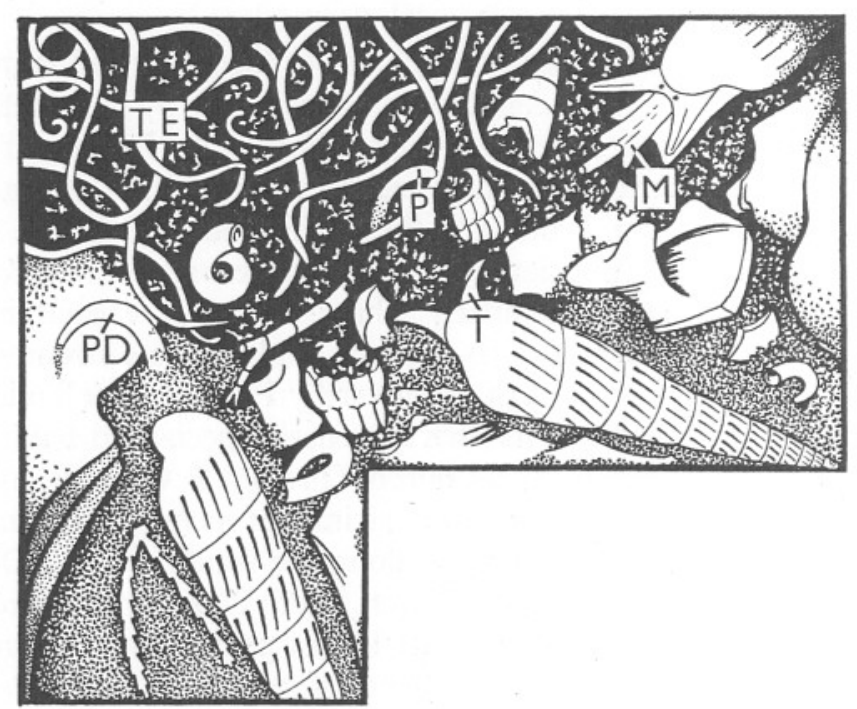

Fig. I. Turbonilla elegantissima feeding on tentacles of Audouinia tentaculata. $\times 7$ : M, mentum through which proboscis is everting; p, proboscis sucking tentacle of Audouinia - its base is buried in silt; PD, retracting proboscis-detritus leaves it as it retracts; T, tentacle of Turbonilla; TE, tentacle of Audouinia.

The differences between the structure of Turbonilla and Odostomia, some of which may be correlated with the differences in habit, will be emphasized in the following description.

The slender shell, so easily pulled through the silt, is too long to be held erect when the mollusc comes to the surface and creeps along the shore, and it is then dragged awkwardly behind the short foot. The exposed parts of the body are white and, as in closely related opisthobranchs, are withdrawn into the calcareous shell and shielded by the operculum when the animal is disturbed. The operculum is orange and lacks the teeth which in Odostomia project into the flesh of the foot. The foot is truncated in front, the antero-lateral corners slightly emphasized, and posteriorly it tapers to a blunt point. The sole is 
covered with columnar epithelium, strongly ciliated, and the same epithelium spreads over the upper surface of the propodium to surround the opening of the anterior pedal mucous gland, and covers the dorsal surface of the mentum. Elsewhere over the foot cilia are more infrequent. The mentum (Fig. I, $M$ ) is a rectangular outgrowth from the foot, narrow in the transverse plane, and it lies between and beneath the tentacles. It differs from the mentum of Odostomia in that the introvert, instead of opening above it, extends through it and opens subterminally on the dorsal surface by an inconspicuous aperture. The introvert opens in the same position in Turbonilla jeffreysii. A median longitudinal furrow runs along the dorsal surface of the mentum above the introvert, and extends to the tip, that is, beyond the mouth. The furrow is lined by cuticularized cells. When the proboscis is to be used the mentum is extended in the direction of the food and held taut, and while the proboscis is gradually everting and pushing through the sand the antero-lateral corners of the tip of the mentum may be pressed against the substratum to give support.

Within the tissues of the foot, and spreading into the haemocoel of the head anterior to the nerve ring, are large numbers of mucous cells. Their contents are discharged by ducts passing between the epithelial cells of the foot. Such cells comprise the anterior pedal gland which opens on the dorsal surface of the propodium. A second large grouping discharges to the entrance of the penial sheath situated beneath the mentum, and a third, more diffuse, lubricates the surface of the sole especially the posterior half. Another type of gland cell is found within the foot forming on each side a lateral glandular streak as in Odostomia and in Patella (Yonge, 1947). Each cell is spherical, filled with globules responding to basic stains and surrounded by a lattice of muscle fibres which may help to discharge the secretion. The epithelium along the sides of the foot, on to which the ducts of these glands discharge, has scattered cells bearing bundles of long cilia; these may be sensory in nature. Similar cells are also found on the ventral surface of the mentum which is otherwise free from cilia.

The head bears a pair of black eyes closely set between a pair of tentacles (Fig. I, T). The latter are of the typical pyramidellid type, shaped like the ears of a rabbit with a concave outer surface, though freely movable so that the concavity may face in a variety of directions. Invariably when the mollusc is burrowing and the tentacle is pressed back the concavity is lateral; the anteriorly directed surface which is pushed through the silt and sand is thickly ciliated, the cilia directing particles towards the tip. These cilia, together with those on the propodium and the dorsal surface of the mentum, form a cleansing current which sweeps sand and silt posteriorly over the head and out to each side. The posterior surface of the tentacle is not ciliated except for the rim bordering the concavity, and the epithelium of the concavity has only scattered tufts of cilia; these may be sensory. The tentacles of Odostomia are held erect when the mollusc is active, perhaps to sample the water, or to sense currents in its 
vicinity: this function would appear to be less significant in Turbonilla, which also lacks the ganglionic mass in the core of each tentacle.

The mantle cavity is deep and narrow. From it have disappeared the osphradium and ctenidium, and the opening of the hermaphrodite duct has been removed to a more anterior position. The rectum and kidney discharge into the posterior half. The anus is on the floor at the posterior end on the extreme right side, and the renal aperture is on the roof at the apex of a papilla which is at the anterior end of the kidney, about halfway along the mantle skirt, slightly to the left of the median line. The kidney lies wholly within the mantle skirt, occupying the posterior half of the left side, and its blood drains to the large efferent pallial vessel which courses along the left wall of the kidney to the auricle. A low, cubical, or even squamous, epithelium lines the greater part of the mantle cavity and permits ready exchange of respiratory gases between the water in the cavity and the blood vessels in the mantle skirt. Beneath this epithelium along the right wall is a strip of gland cells arising near the anus, which broadens as it passes anteriorly. Here the gland cells become larger and fewer. There appear to be two types of cell comprising this strip: one, the larger, elaborates secretory masses of irregular shape which stain deeply at first with iron haematoxylin, but near the time of liberation stain less intensely; whilst the second is filled with granules shaped like rice grains and always staining deeply with basic dyes. The secretion from these glands presumably helps to lubricate the passage of the faeces, supplementing the meagre secretion from the short intestine. On entering the anterior half of the mantle cavity the glandular strip leaves the mantle skirt and passes ventrally to the dorsal wall of the body along which it runs, first to the right of the pallial hermaphrodite duct and then above it.

The anterior half of the mantle cavity contains two important structures: the hypobranchial gland, which spreads along the roof anterior to the kidney and approaches the pallial edge, and, along the right wall, an exhalant gutter which is extended anteriorly beyond the mouth of the shell into a spoonshaped siphon. The gutter arises anterior to the point at which the strip of subepithelial gland cells, running forwards from the anus, passes medially on to the body wall. It is bordered on either side by a narrow strip of tall columnar epithelium, about a dozen cells broad, which is covered with long, closely set cilia. Between these bands the epithelium contains brown pigment granules and is not ciliated. One band runs along the mantle skirt on its extreme right side, and the other lies on the body wall immediately beneath it keeping to the right of the genital duct. Posteriorly the two converge and unite. The effective stroke of the cilia directs particles mixed with hypobranchial secretion forwards into the exhalant channel. The same general arrangement of this cleansing path from the mantle cavity is found in Odostomia (Fretter \& Graham, 1949) and also in Omalogyra and Rissoella (Fretter, 1948); it appears more important in Turbonilla, and, while the animal burrows, a rope of detritus adhering to 
secretion is poured from the mantle cavity by its activity. In all of these gastropods gill filaments have been lost, and their function of maintaining a stream of water through the mantle cavity is taken over by the ciliated strips of columnar epithelium along the exhalant path; the vascularized mantle skirt takes over the respiratory function of the gill.

At the anterior edge of the mantle skirt the epithelium is columnar, and in the pallial thickness is a complicated musculature and many mucous glands which discharge on to the surface.

In Odostomia the opening of the hermaphrodite duct is just within the mantle cavity, and from it a ciliated tract directs spermatozoa around the base of the right tentacle to the penial sheath. In Turbonilla the pallial duct is extended forward in the direction of the ciliated tract and opens on the propodium in front of the right tentacle and to the right of the mentum: in fact the common genital aperture is anterior to the opening of the penial sheath. Yet another opening lies on the side of the head, just behind the genital one and slightly more median. It is the duct of a muscular pouch which lies in the haemocoel and may be associated with the genital system.

Differences between the alimentary canal of Turbonilla and Odostomia are for the most part insignificant. The acrembolic proboscis grips the tentacle of the host with a sucker, formed from modified lips, and the piercing action of the stylet is synchronized with the attachment. The stylet is short, occupying only one-tenth of the length of the fully extended proboscis as compared with one-third in Odostomia; such a short stylet is not found in Turbonilla jeffreysii, an ectoparasite of hydroids and the only other member of the genus which has been studied. As in this species, however, and in contrast to Odostomia, the oral tube is not divided into a dorsal channel for the stylet and a ventral food channel: the sucker surrounds a single opening through which the stylet protrudes and into which the food is drawn. The cuticle comprising the stylet is secreted from the dorsal wall of the oral tube, like the jaws of more unspecialized gastropods. It extends forwards to embrace, and to envelop anteriorly, a projection arising from a more posterior part of the dorsal wall of the oral tube and passing through it to the sucker. This projection, forming the core of the stylet, contains the fused salivary ducts which open at the tip of the spike, and must pour secretion into the wound inflicted by it. Posteriorly the median salivary channel enlarges to a club-shaped origin, a region that invariably contains some saliva. Its walls are thickened by a complexity of muscles in which are embedded the ends of the salivary ducts and which are responsible for the movements of the stylet.

The oral tube has a low cubical epithelium which turns outwards over the sucker to meet the epithelium of the introvert; only at the periphery of the sucker is the epithelium ciliated. The ciliated cells, forming a ring not more than a dozen cells broad, flick particles away from the mouth as the proboscis is pushed through the silt. The intrinsic musculature of the sucker is arranged 
as in Odostomia, though the longitudinal fibres, attached at their outer ends to the underside of the epithelial cells, are longer, giving the sucker a greater depth. This muscular region is followed by a short section of the tube in which there are large subepithelial glands discharging their secretion into the lumen; in their detailed structure these resemble glands which occur in the long oral tube in Turbonilla jeffreysii (Fretter \& Graham, 1949, fig. 5). The buccal pump arises from the ventral wall of the tube at about two-thirds of its length from the anterior end. Its low, cuticularized epithelium overlies a thick wall composed chiefly of radial muscle fibres with antagonistic transverse fibres. This musculature sets up a rhythmical pumping action when the parasite is feeding. The pump is small as compared with that of Odostomia, lies hidden beneath the oral tube and has no caecum; its size may be correlated with the shortness of the oral tube. All its contractile cells contain groups of fibrillae which are striated. There are some mucous cells in and under the epithelium at the posterior end of the pump, especially around its opening to the oesophagus which is on a small papilla projecting into the narrow oesophageal tube.

The epithelium of the introvert is not complex as in other pyramidellids. It is columnar and cuticularized, showing no regular papillation. In the living tissue two types of subepithelial gland cell can be distinguished: in one the cytoplasm contains colourless spherules and in the other it appears as a granular fluid of homogeneous consistency. Occasionally these gland cells occur in the epithelium. Circular muscle fibres constituting a coat of considerable thickness lie directly beneath the epithelium, and then come the longitudinal muscles which are responsible for the retraction of the extended proboscis. They take the same course as the retractors of the proboscis of Odostomia. As the proboscis is retracted small particles of detritus and diatoms are frequently drawn in with it (Fig. I, PD): on its protrusion they fall off the smooth surface or are scraped off as it pushes through the substratum. The eversion of the proboscis is mainly brought about by the hydraulic action of the blood in the cephalic haemocoel. To provide for the disturbances in the vascular system which such profound changes in shape of the anterior part of the body must entail the arrangement of this system is modified to what must be regarded as the typical pyramidellid plan. A single aorta arises from the ventricle and passes up the visceral mass to open into haemocoelic spaces. The anterior aorta has no direct connexion with the heart, but runs between a vast haemocoelic sinus which bathes the pericardium and adjacent reproductive organs, and the haemocoelic spaces of the head and foot. Blood will flow anteriorly through the aorta when the proboscis is thrust out, and when it is withdrawn may be forced back In this way the reverse direction to fill the posterior haemocoelic reservoir. rapidly in injury to the heart by the sudden pressure of returning blood is prevented.

In Odostomia the large buccal ganglia are situated at the anterior end of the buccal pump which is regarded as part of the modified buccal cavity, the tube 
of capillary dimensions which leaves the pump being the oesophagus. In Turbonilla the ganglia are more posterior and lie near the point at which the salivary ducts leave their glands. This point may appear half-way along the muscular tube which connects the pump with the stomach, though when the proboscis is in use the part of the tube posterior to the ganglia may be extended to twice or even thrice the length of the anterior section. With the extreme specialization of the anterior part of the alimentary canal in the pyramidellids the buccal ganglia may shift from their original position. In Cerithiopsis tubercularis (Fretter, I95 I), which shows modifications associated with a much less specialized type of proboscis, the ganglia lie at the posterior end of the anterior oesophagus where the salivary ducts leave the haemocoel and penetrate the musculature of the oesophagus within which they make their way to the buccal cavity. A similar course is followed by these ducts in Turbonilla. The region of the alimentary canal between buccal pump and buccal ganglia may, therefore, be regarded as the anterior oesophagus. It is a long muscular tube of uniform diameter which lies in tangled coils in the haemocoel when the proboscis is retracted, and is carried out into the proboscis when it is everted. The section of the oesophagus behind the buccal ganglia is of uniform structure throughout, and is only distinguishable from the anterior part by its musculature. The oesophageal epithelium is similar from one end to the other, being composed of low columnar cells.

The intrinsic muscles of the anterior oesophagus constitute a coat of circular fibres beneath the basement membrane of the epithelium, and an outer coat of longitudinal fibres; the salivary ducts run just within the latter. These muscles set up a peristaltic movement which can be seen when the living animal is dissected. In the wall of the posterior part of the oesophagus there are no circular muscles: its whole movement is controlled by a complex arrangement of longitudinal fibres grouped into compressed sheets which lie radially with respect to the lumen; the nuclei of the muscle cells border the haemocoel. Only the anterior part of this section of the oesophagus is drawn out into the proboscis.

Each salivary gland consists of a narrow tube, ciliated and surrounded by subepithelial gland cells except at the innermost end where the lumen swells into a thin-walled bladder lined by cubical cells without cilia. Strands of muscle attach this bladder to the wall of the posterior part of the oesophagus. The gland is connected to the stylet by a long duct which leaves its anterior end and, after a very short course in the haemocoel, passes into the intrinsic longitudinal muscles of the anterior oesophagus. The duct appears minute in transverse section, with three low epithelial cells surrounding the lumen and beneath these muscle cells containing circularly running fibrillae. Anteriorly the two ducts leave the oesophagus and pass dorsally to enter the median salivary channel which lies within the stylet. Most of the secreting cells of the gland have a similar appearance-very finely vacuolated cytoplasm which 
stains lightly with basic dyes and also with stains specific for mucus. The nuclei are relatively enormous and have many granulations and three or four nucleoli. There may be, as in Odostomia, a holocrine secretion occurring without a restitution phase: there is evidence from the appearance of the gland that new cells are formed only at the innermost end, near the terminal bladder, and spent cells, destroyed after secreting, are restricted to the region at the beginning of the duct.

When the proboscis is withdrawn the muscles of the posterior half of the oesophagus contract, shortening and broadening that tube, which comes to rest beneath the coiled anterior oesophagus and just above the columellar muscle. Posteriorly the oesophagus opens to the stomach, which is ill-defined except for its anterior wall, and which cannot elsewhere be distinguished from the digestive gland. The anterior wall is made of a small area of columnar epithelium which surrounds the oesophageal opening and the opening of the intestine lying above this. Thus the food, which is liquid and so needs no mechanical treatment before it can be absorbed, is passed from the oesophagus directly to the cells of the digestive gland; in these cells it appears, at first, in the form of brown spherules. The only waste matter which is seen in the intestine is derived from the digestive cells of the digestive gland, and is in the form of small yellow and green concretions. The intestine passes from the stomach directly to the upper end of the mantle cavity. The epithelium is ciliated and has a few scattered gland cells in which secretion spherules stain readily with basic dyes.

The important dissimilarities between the hermaphrodite reproductive systems of Odostomia spp. and Turbonilla elegantissima concern the length of the pallial duct and the organs of copulation. Perhaps of less significance are other divergent characters which are related to the accessory glands, both albuminous and mucous, and the histology of the pallial duct.

The gonadial channel which links the hermaphrodite gland with the pallial duct receives, in Turbonilla, a single duct which drains both the albumen and mucous glands. These glands, lying in the upper visceral coils, have, in Odostomia, separate ducts which converge on approaching the gonadial duct so that their openings to it are set very close together. The ducts have apparently fused in Turbonilla. A second mucous gland occurs in Odostomia and surrounds the upper end of the pallial duct, where the body broadens to its last coil, and when the female system is mature this gland spreads half-way along the duct. In Turbonilla elegantissima the distal mucous gland is confluent with the proximal one: a single gland, lobed and presumably not entering the last coil, has one outlet to the genital duct and a second, by a broad secretory channel, to the innermost end of the pallial duct.

The pallial duct extends on to the propodium and has, for more than half its length, an epithelium of tall columnar cells bearing long cilia. This distal region of the duct is very muscular. Elsewhere the ciliated cells lie between gland 
cells swollen with secretion. The gland cells are of three principal types. The most important, occurring in the centre of the secreting area and-a few-at the proximal end of the duct, contains large spherules of mucus; distally, between these and the ciliated part, and sometimes scattered amongst the mucous cells, are glands with smaller secretion globules which stain deeply with basic dyes; whilst at the proximal end of the duct the secretion within the cells, again in the form of spherules, is not mucus and stains with basic dyes only lightly. Surrounding the opening of the gonadial duct is yet another type of gland cell: the enormous nucleus is probably indicative of intense metabolic activity; the spherules of secretion stain deeply (iron haematoxylin) during their period of elaboration, but lightly near the time of liberation. This varied histological structure of the duct contrasts with the uniformity in Odostomia.

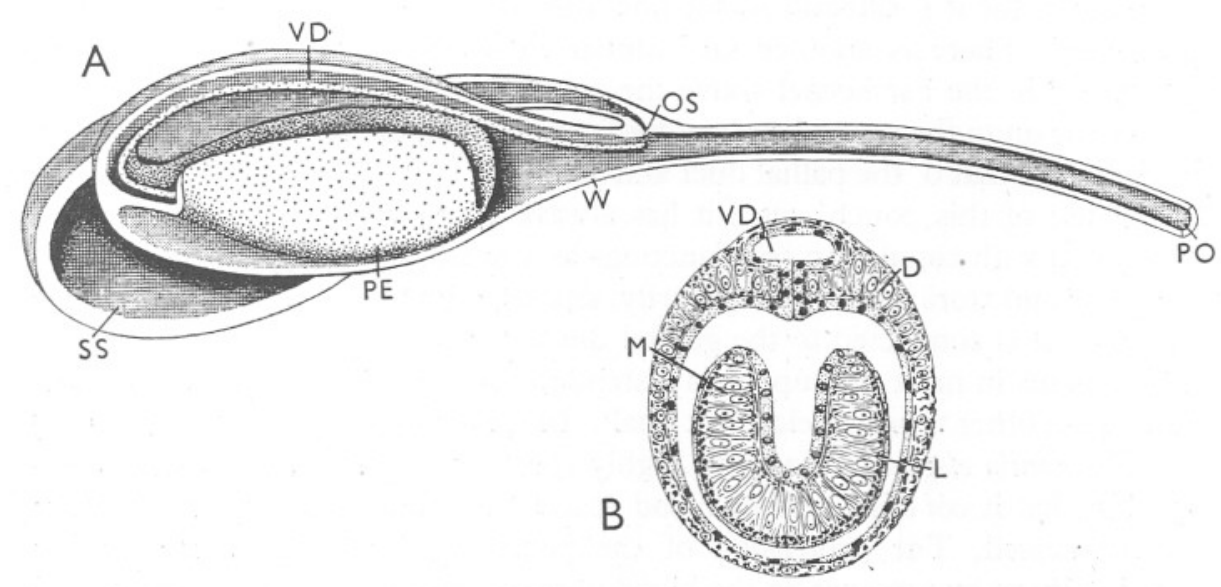

Fig. 2. Turbonilla elegantissima. A, Copulatory organs. The right wall of the sperm sac, the penial sheath, the vas deferens and of the posterior part of the penis has been removed. $\times$ I22. B, Transverse section through penis and its sheath. $\times 27$ I. D, dilator muscles of penial sheath; L, longitudinal muscles of penis; $M$, muscles running between epithelia of penis; OS, opening of sperm sac into penial sheath; PE, penis; PO, opening of penial sheath beneath mentum; ss, sperm sac; vD, vas deferens; w, wall of penial sheath.

The penis is invaginable (Fig. 2A, PE), as in other pyramidellids, and when at rest lies in the haemocoel, retracted into a tubular sheath $(\mathrm{w})$ with which its walls are confluent. The sheath is broad posteriorly where the retracted penis lies, and its narrow anterior end passes through the nerve ring to open beneath the mentum (PO). It is ventral to the introvert. A large muscular pouch, the sperm sac (ss), lined by a low columnar epithelium on which fine cilia are closely set, opens into the dorsal wall of the sheath, in front of the tip of the retracted penis. The opening is surrounded by a sphincter. The structure of the penis is unusual in that it contains neither blood spaces nor duct. When retracted into the sheath it has the appearance of a long muscular scoop 
attached posteriorly to the wall of the sheath. On to its concave surface, at the posterior end, opens the vas deferens, which is a deep longitudinal groove running along the dorsal wall of the sheath between the mouth of the sperm sac and the base of the penis. The lips of this groove (at least in fixed and dissected specimens) are firmly pressed together so that it may function as a duct. The vas deferens, the rest of the sheath and the penis are covered by cuticularized epithelium. The entire space between the upper and lower epithelia of the penis is occupied by three sets of intrinsic muscles: one series of fibres runs between the two epithelia (Fig. $2 \mathrm{~B}, \mathrm{M}$ ); antagonizing these are bundles of longitudinal fibres under the lower epithelium (L); and, beneath the upper epithelium, on to which the vas deferens discharges, fibres run transversely from edge to edge with a few running longitudinally. It is assumed that, as in Odostomia spp., the sperm sac is filled with spermatozoa prior to copulation, for it is difficult to see how they could reach it when the penis is protruded. There is another sac, similar in histology and slightly smaller, which lies in the haemocoel above the anterior end of the retracted introvert and opens on to the propodium not far from the genital aperture. The opening is median to that of the pallial duct and posterior to it. There is no evidence as to the use of this pouch, since it has always appeared empty. Perhaps it is concerned with copulation and functions as a bursa, receiving the sperm from the penis and storing them temporarily, and expelling them later to the groove by which it is connected to the genital duct.

The penis in most gastropods is distended with blood at the time of copulation and at other times is relatively small. In Omalogyra atomus (Fretter, I948) and Turbonilla elegantissima, both highly specialized species, the organ is unusual in that it contains neither blood spaces nor glands and the musculature is pronounced. The protrusion of the penis in Turbonilla is presumably brought about by pressure on the blood in the haemocoel aided by the muscles of the penial sheath.

The eggs of T. elegantissima are not known. Lebour (1936) describes and figures the young which even when very small $(0.25 \mathrm{~mm}$. across the shell) may be found with the adults in muddy and stony ground. She suggests that there is a very short free-swimming stage in the life history, and this would agree with what happens in species of Odostomia.

\section{SUMMARY}

Turbonilla elegantissima is a pyramidellid, ectoparasitic on Audouinia tentaculata and Amphitrite gracilis, attaching to the tentacles, and sometimes to the gills of Amphitrite, by means of an oral sucker, piercing by a stylet-a modified jaw-and sucking its food by a buccal pump. It burrows in silt.

The alimentary canal varies from the structure in Odostomia and Chrysallida in details which are relatively unimportant and confined to its highly modified 
anterior part. Thus the stylet, and consequently the oral tube, is very short, and in the tube there is only one channel for both stylet and food; the opening of the introvert is on the dorsal surface of the mentum, subterminally, and the surface of the introvert is not papillated; the buccal pump is short, arising behind the sucker, and has no caecum; the oesophagus is divisible into anterior and posterior sections, distinguished by their musculature and by the fact that the salivary ducts run within the longitudinal muscles of the anterior part.

In the reproductive system there is greater specialization than in Odostomia and Chrysallida: for the opening of the pallial hermaphrodite duct is on the propodium. The penis, scoop-shaped and concealed within a sheath, has neither blood spaces nor duct, and its musculature is pronounced. There is a muscular pouch in the haemocoel of the head, opening on the propodium close to the hermaphrodite genital aperture, which may be a bursa copulatrix.

\section{REFERENCES}

Allen, E. J. \& Todd, R. A., I900. The fauna of the Salcombe Estuary. Fourn. Mar. Biol. Assoc., Vol. vi, pp. I5I-2I7.

Forbes, E. \& HANLEY, S., I853. British Mollusca. London.

FRETTER, V., I948. The structure and life history of some minute prosobranchs of rock pools: Skeneopsis planorbis (Fabricius), Omalogyra atomus (Philippi), Rissoella diaphana (Alder) and Rissoella opalina (Jeffreys). Fourn. Mar. Biol. Assoc., Vol. XxvII, pp. 597-632.

- 1951. Observations on the life history and functional morphology of Cerithiopsis tubercularis (Montagu) and Triphora perversa (L.). Fourn. Mar. Biol. Assoc., Vol. xxix, pp. 567-86.

Fretter, V. \& Graham, A., I949. The structure and mode of life of the Pyramidellidae, parasitic opisthobranchs. Fourn. Mar. Biol. Assoc., Vol. xxvIII, pp. 493-532.

Jefrreys, J. G., I867. British Conchology, Vol. Iv. 486 pp. London.

LeBour, M. V., I936. Notes on the eggs and larvae of some Plymouth prosobranchs. Fourn. Mar. Biol. Assoc., Vol. xx, pp. 547-65.

Marine Biological Association, 1931. Plymouth Marine Fauna (2nd. ed.). Plymouth.

YONGE, C. M., I947. The pallial organs in the aspidobranch Gastropoda and their evolution throughout the Mollusca. Phil. Trans. Roy. Soc. London, B, Vol. cCXxxII, pp. 443-518. 